\title{
Magnesium Glycinate
}

National Cancer Institute

\section{Source}

National Cancer Institute. Magnesium Glycinate. NCI Thesaurus. Code C76082.

An orally available magnesium salt of glycine. Magnesium activates over 600 enzymes and is essential for DNA and RNA synthesis, cellular repair, and maintaining the antioxidant status of the cell. Magnesium plays a key role in bone and muscle function and assists in the activation of vitamin $\mathrm{D}$, which helps regulate calcium and phosphate homeostasis to influence the growth and maintenance of bones. 